${ }^{\bullet}$ Entomologica Fennica. 3.XII.1992

\title{
The lateralis group of the genus Dimorphocoris Reuter of Greece and the Middle East (Heteroptera, Miridae, Halticini)
}

\author{
Rauno E. Linnavuori
}

Linnavuori, R. E. 1992: The lateralis group of the genus Dimorphocoris Reuter of Greece and the Middle East (Heteroptera, Miridae, Halticini). Entomol. Fennica 3:215-222.

The taxonomy and distribution of the lateralis group of the genus Dimorphocoris Reuter of Greece and the Middle East is described. New species: Dimorphocoris sari sp. n.

Rauno E. Linnavuori, Somersoja, SF-21220 Raisio 22, Finland

The genus Dimorphocoris Reuter, which is distributed from the Mediterranean region to Central Asia, contains numerous species. Many of them have a very restricted range, undoubtedly owing to a low capacity for movement caused by the brachypterism of females or of both sexes. A revision of the genus has been published by Wagner (1965 and 1973).

The genus contains two groups: the gracilis group in which males are macropterous and females brachypterous and the lateralis group in which both of the sexes are brachypterous. The species of the latter group inhabiting Greece and the Middle East are revised here. They form three phylogenetic subgroups:

1) In D. sari sp. n., D. saulii Wagner (Jugoslavia, Trieste) and D. servadeii Tamanini (Italy, the Apennines) males are gracile, nearly parallel-sided and the dorsal margin of the genital opening is provided with a median tooth. All of them are montane species with a restricted range.

2) D. lateralis Reuter, D. eckerleini Wagner and D. punctiger (Horváth) (males pyriform, dorsal margin of genital opening edentate) are closely related species, certainly recognized by the male genital structure only. $D$. lateralis is the northernmost species, which is distributed from Libya through Crete to Kos, Naxos and Rhodes. D. eckerleini has a more southern range extending from Libya to Cyprus and northern Israel. D. punctiger is known only from Syria. Species of this group live on grasses in hilly habitats.

3) D. tristis (Fieber) can be recognized by the small size, pale coloring, incrassate hind femora, wide Holomediterranean distribution, and special biology in sandy coastal habitats.

Key to the Dimorphocoris species of the lateralis group:

Males

1. Small pale species, length $2 \mathrm{~mm}$. Hind femora incrassate .......................................................... tristis

— Larger and darker species. Hind femora more slender

2. Body elongate (Fig. 1), nearly parallel-sided, largely black. 1st antennal joint black .............................. sari

- Body pyriform with more intense pale pattern. 1st antennal joint pale 3

3. Tibiae immaculate. Median process of vesica (Fig. 7a-b) gracile, narrowly blade-like, smooth .. lateralis

- Tibiae with small dark setigerous dots. Median process of vesica dentate

4. Dark pattern sharply contrasting (Fig. 6a). Median process of vesica sharply claw-like (Fig. 7e-f)

eckerleini

- Dark pattern less intense. Median process of vesica short, digitate (Fig. 7m-n) punctiger 


\section{Females}

1. Small pale species, length $2.7-3.0 \mathrm{~mm}$. Elytra very short, roundish (Fig. 6d). Hind femora incrassate ....... tristis

- Larger and darker species. Elytra longer. Hind femora more slender

2

2. Under surface of 1 st antennal joint and dorsum of abdomen black ................................................. sari

- 1st antennal joint yellowish brown. Dorsum of abdomen not uniformly black

lateralis

3. Tibiae immaculate

- Tibiae with small dark dots .... 4

4. Length $3.0-3.5 \mathrm{~mm}$. 2nd antennal joint twice as long as synthlipsis, $1.18 \times$ as long as diatone ......eckerleini

- Length 3.50-3.75 mm. 2nd antennal joint 1.55-1.66× as long as synthlipsis, $0.90-1.0 \times$ as long as diatone ..

punctiger

\section{Dimorphocoris sari sp. n.}

Figs. 1-2

Material: Greece: Peloponnesus, Mt. Taigetos above Anogia, alt. 1900 m, ơ holotype, 19.VI.1990, 2 o' o', 1 ㅇ paratypes, 2.VI.1989, 1 o' 2 우 paratypes, 19.VI.1990, Linnavuori, in coll. Linnavuori.

Diagnosis: Recognized by the large size, dark coloring and the structure of the male genitalia.

Description: Brachypterous. Length $\bigcirc^{7} 3.25$ $\mathrm{mm}$, o $3.75 \mathrm{~mm}$.

Male. Head black, with narrow broken median line and spot on vertex near each eye pale ochraceous. Eyes brown. Antennae black, 2nd joint yellowish brown with apex \pm embrowned, extreme base of 3rd joint also pale. Pronotum black, narrow median line and the very lateral margins pale ochraceous. Scutellum black, with narrow pale median line, sometimes only tip pale. Elytra black, lateral margins broadly pale ochraceous. Medioapical angle also pale. Dorsum of abdomen uniformly black, paratergites pale with brown spots. Under surface black, sides of head pale, pro-, meso- and metapleura at least marginally pale, parasternites pale with dark spots. Femora black with tips pale. Tibiae ochraceous with small dark spots, tips of tibiae and entire tarsi black. - Body elongate, nearly parallel-sided, 2.8-3.0 $\times$ as long as broad at broadest point of abdomen. Upper surface with black bristles, long semidecumbent brownish hairs and adpressed silvery pubescence. Head $1.15-1.20 \times$ as broad as pronotum, in apical view
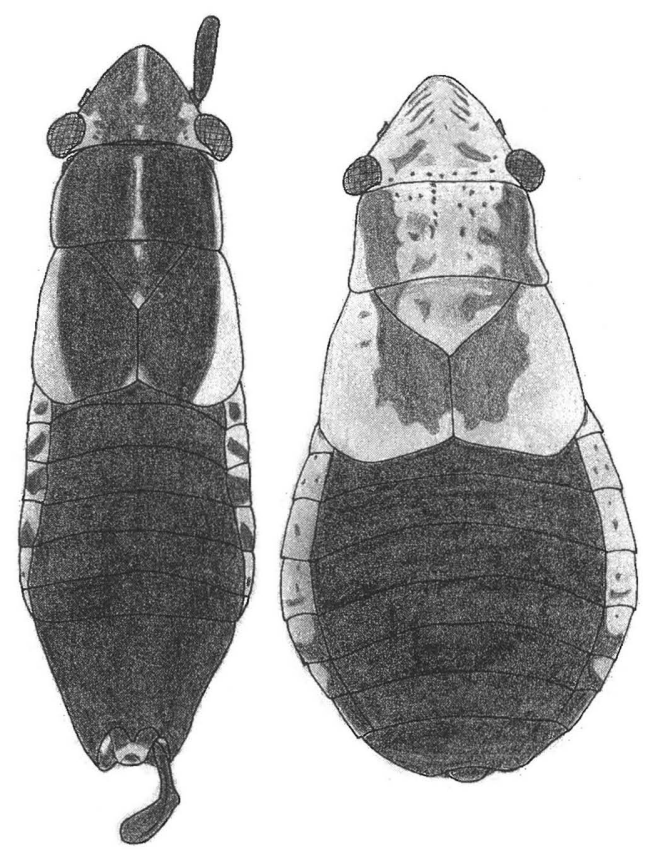

Fig. 1. Dimorphocoris sarisp. n. Male (left) and female (right).

1.16-1.22 $\times$ as broad as high; ocular index 2.442.70. Antennae long and gracile, proportions between joints 31:84:68:36, 1st joint 0.94-0.97 $\times$ as long as synthlipsis; 2 nd 2.54-2.80 $\times$ as long as synthlipsis, $1.40-1.56 \times$ as long as diatone, $1.70-$ $1.86 \times$ as long as basal width of pronotum. Rostrum extending a little beyond hind coxae. Pronotum about $1.9 \times$ as broad as long in middle, lateral margins subparallel, only slightly diverging caudad. Elytra about $1.26-1.36 \times$ as long as broad, costal margins subparallel, apical margins obliquely truncate. Abdomen elongate, lateral margins subparallel. - Male genitalia in Fig. 2. Pygofer relatively short, broadly conical; dorsal margin of genital opening with distinct median lobe. Right style rather straight, enlarged apical portion elongae, apical tooth claw-like. Left style and structure of vesica as in Fig. 21-0.

Female. Head, pronotum, scutellum, and elytra yellowish brown with brown or blackish markings as seen in Fig. 1. Eyes brown. 1st antennal joint ventrally black, dorsally yellowbrown with a few brown spots, 2nd joint yellow- 

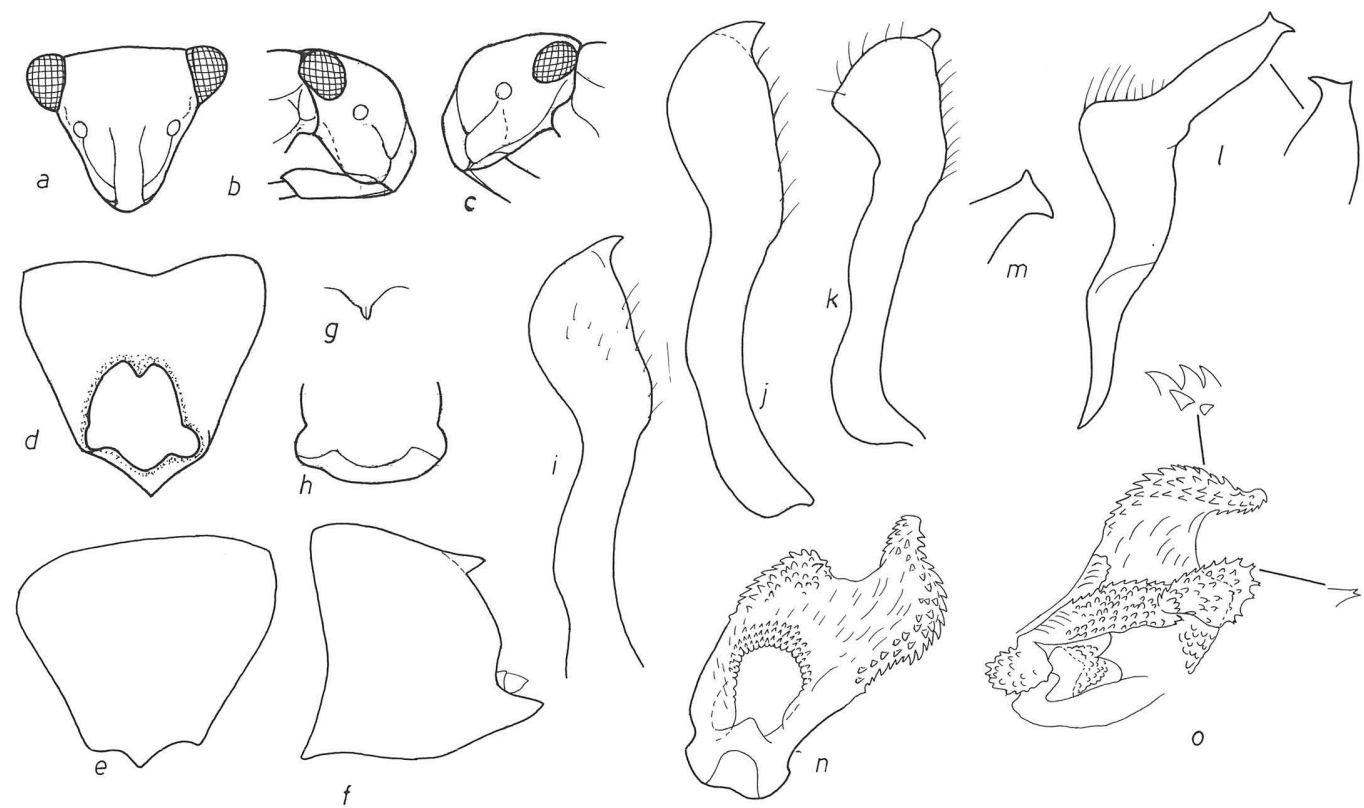

Fig. 2. Dimorphocoris sari sp. n. a-b: male head in apical and lateral view; c: female head in lateral view; $d-f$ : pygofer in dorsal, ventral and lateral view; g: dorsal process of genital opening; h: ventral margin of genital opening; i-k: right style; l: left style; m: apex of hypophysis of left style; n-o: structure of vesica.

brown, other joints black, base of 3rd pale. Elytra nearly uniformly pale or medially broadly embrowned. Dorsum of abdomen uniformly black, paratergites pale with dark spots. Under surface pale, medially black. Legs pale; femora with abundant, often \pm confluent dark spots, hind femora on dorsal surface \pm largely black. Tibiae with small dark dots. Tarsi black. - Body pyriform, 1.90-2.14 $\times$ as long as broad at broadest point of abdomen. Hair covering as in $\sigma^{7}$. Head $1.1-1.2 \times$ as broad as pronotum, in apical view 1.10-1.23 $\times$ as broad as high; ocular index 2.863.10. Antennae long and gracile, proportions between joints 27:61:55:40, 1 st joint $0.68 \times$ as long as synthlipsis; 2nd 1.53-1.68 $\times$ as long as synthlipsis, $0.90-0.92 \times$ as long as diatone, 1.0$1.07 \times$ as long as basal width of pronotum. Pronotum about $2.1 \times$ as broad as long in middle, lateral margins subparallel, with slight subbasal insinuation. Elytra about $1.16 \times$ as long as broad, costal margins smoothly diverging caudad, apical margins subtruncate. Abdomen elongately ovate, $1.22-1.40 \times$ as long as broad.
Biology: On grasses in a luxuriant moist meadow in the coniferous zone of Mt. Taigetos.

Etymology: The species is dedicated to Miss Sari Kuivalainen, of Turku, Finland, who attended my recent expedition to the Hadhramaut.

The new species is closely related to $D$. saulii Wagner and $D$. servadeii Tamanini.

\section{Dimorphocoris saulii Wagner, 1965}

Fig. $3 \mathrm{a}-\mathrm{i}$

Material: Jugoslavia, Trieste, Auremiano, $\sigma^{7}$ and $ᄋ$ paratype, 2 O' $^{7}$, VII.1940, L. Sauli, in Mus. Hamburg.

Description in Wagner 1965:155 and 1973:93-94.

Smaller, length Ơ $^{7} 3 \mathrm{~mm}$, o $3.0-3.4 \mathrm{~mm}$. Tibiae immaculate.

Male. Antennae shorter, 1 st joint $0.82-0.88 \times$ as long as synthlipsis, 2nd 2.10-2.18 $\times$ as long as synthlipsis, 1.16-1.24 $\times$ as long as diatone, 1.31- 


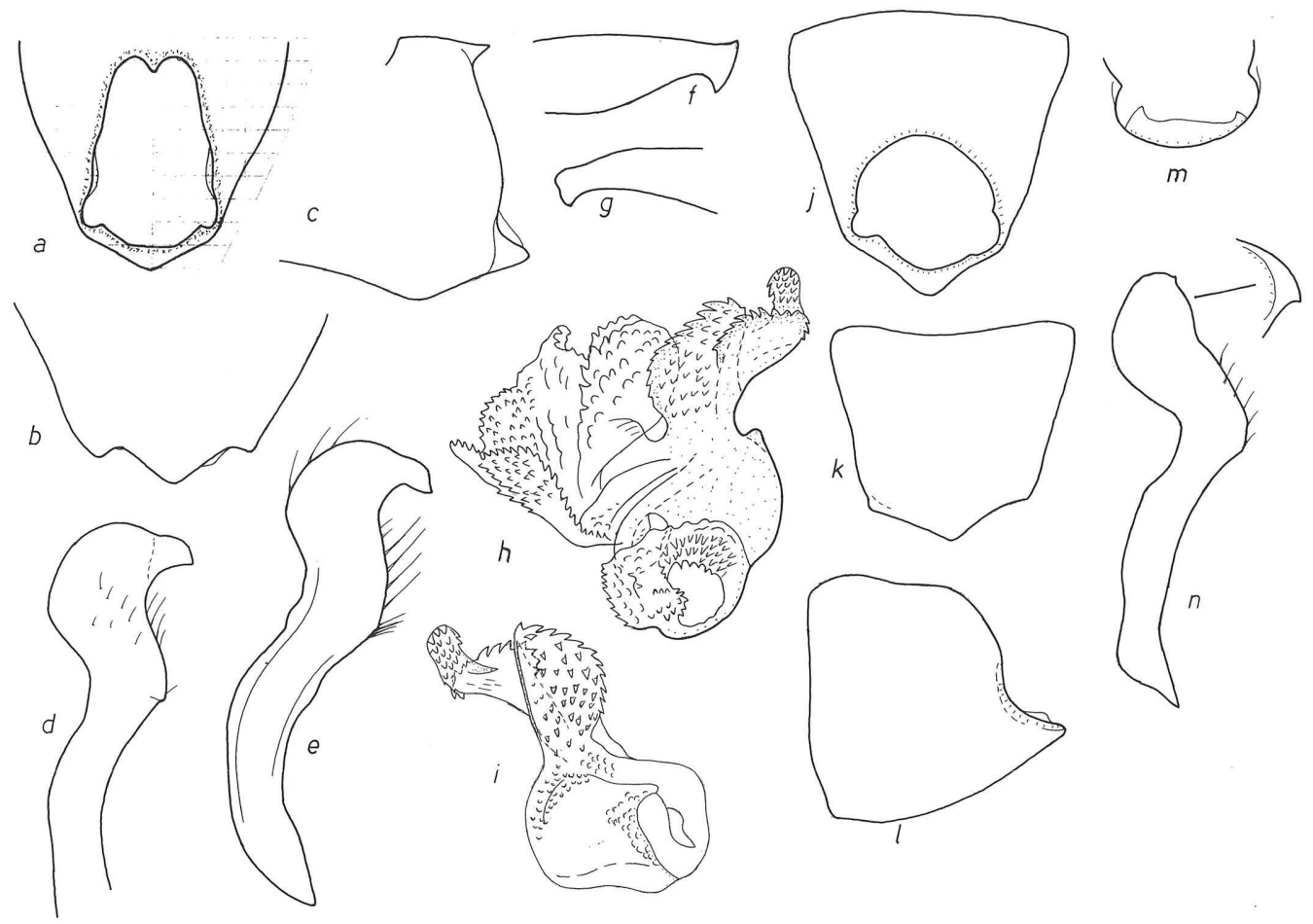

Fig. 3. Dimorphocoris saulii Wagner. a-c: pygofer in dorsal, ventral and lateral view; d-e: right style; f-g: hypophysis of left style; $h$-i: structure of vesica. $-D$. lateralis Reuter. $j-l$ : pygofer in dorsal, ventral and lateral view; m: ventral margin of genital opening; n: right style.

$1.44 \times$ as long as basal width of pronotum. Male genitalia (Fig. 3a-i): Genital opening of pygofer much longer and narrower. Right style: apical portion broader, strongly curved, apical tooth larger. Processes of vesica dissimilar.

Female. Abdomen broadly ovate, $1.11 \times$ as long as broad. 1st antennal joint pale and tergites provided with obscure pale middle spots. cality.

Distribution: Known only from the type lo-

\section{Dimorphocoris servadeii Tamanini, 1982}

Figs. 4-5

Description in Tamanini 1982:335-341.

Length $0^{7} 3.15-3.53 \mathrm{~mm}$, o $3.30 \mathrm{~mm}$.

Male. 1st antennal joint with dark spots. Middle of pronotum largely pale. Scutellum pale. Abdominal tergites also paler. 1st antennal joint
$0.85 \times, 2$ nd $2.18 \times$ as long as synthlipsis. Male genitalia (Figs. $4 \mathrm{~g}$ and $5 \mathrm{c}-\mathrm{h}$ ): Pygofer shorter. Apical portion of right style strongly curved, apical tooth larger. Dentate apical portion of vesica longer, with edentate basal lobe.

Female. Pale with dark margins reduced. Scutellum uniformly pale. Elytra only faintly embrowned. Tergites pale with numerous dark spots. 2nd antennal joint $1.32 \times$ as long as synthlipsis.

Distribution: Italy, Marches and Campania regions of the Apennines.

\section{Dimorphocoris lateralis Reuter, 1991}

Figs. 3j-n, 6b, 7a-b

Types: Crete, Canea, O' lectotype (labeled as "holotype"), designated by Wagner, $\sigma^{7}$ syntype, J. Sahlberg, in Mus. Helsinki. 

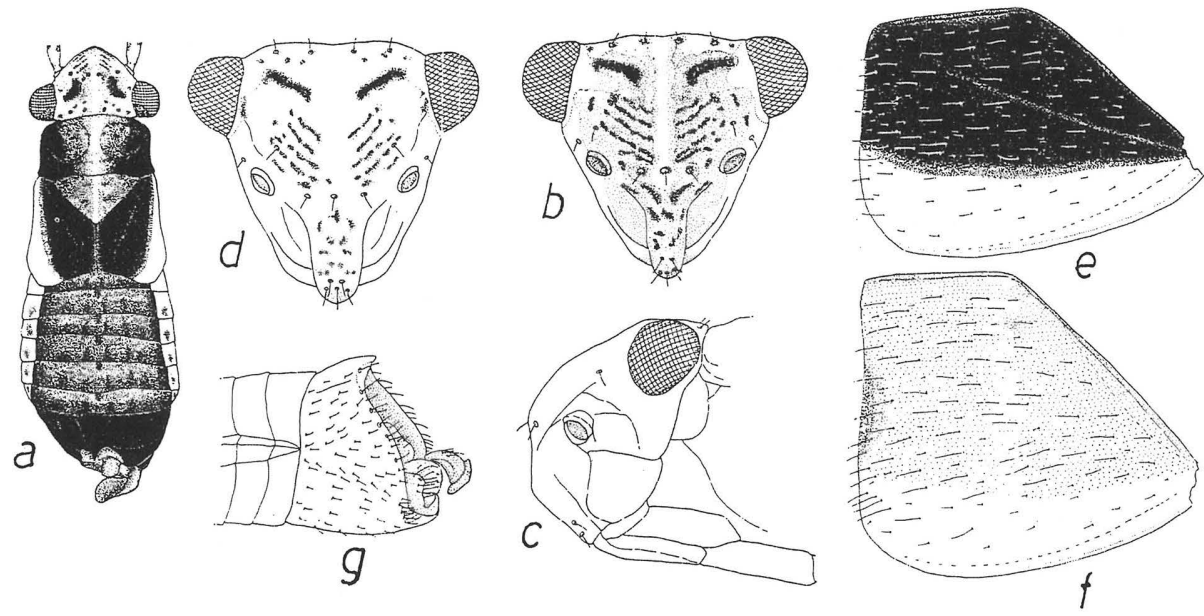

Fig. 4. Dimorphocoris servadeii Tamanini. a: male, dorsal view; b-c: male head in apical and lateral view; d: female head in apical view; e: male elytron; f: female elytron; g: pygofer, lateral view. — After Tamanini 1982.

Material: Greece: Naxos, Chora, 1 ex, 4.V.1982; Moutsouma, 1 ex, 1-3,V.1982, Drosopoulos (specimens recorded as D. punctiger (Horváth) in Josifov 1990:6). Kos, Kardamena, 4 exx, 22.IV.1991, Drosopoulos). Rhodes, several exx from Petaloudes, 28.III.1991 and KalathosAsklipio, 31.III.1991, Linnavuori. — Libya: Cyrenaica, $10 \mathrm{~km}$ El Merj, 1 ex, 22.IV.1965, Eckerlein, in coll. Linnavuori.

Description: Length ơ 2.5-3.0 mm, o 3.25$3.50 \mathrm{~mm}$.

Male. Pattern as in Fig. 6a. Pale ochraceous. Head with two irregular fuscous longitudinal bands. Eyes brown. 1st and 2nd antennal joints yellowish brown, other joints dark brown, base of 3 rd pale. Pronotum blackish, median band, the very lateral margins and two spots in anterior margin pale. Scutellum blackish brown with pale median line. Elytra blackish, lateral margins contrastingly pale. Dorsum of abdomen blackish, connexiva and two longitudinal bands of \pm obscure pale spots on dorsum pale. Under surface \pm largely infuscate. Femora black, tips of fore and middle femora \pm pale. Tibiae yellow-brown, immaculate; tarsi black. Body elongately pyriform, 2.3-2.5 $\times$ as long as broad at broadest point of abdomen. Upper surface with erect dark hairs and appressed silvery pubescence. Head about $1.12 \times$ as broad as basal width of pronotum, in apical view $1.24 \times$ as broad as high; ocular index 2.23-2.40. Proportions between antennal joints $36: 80: 61: 25$; 1 st joint $1.14-1.20 \times$ as long as synthlipsis, 2 nd $2.5-2.9 \times$ as long as synthlipsis, $1.34-1.55 \times$ as long as diatone, about $1.6 \times$ as long as basal width of pronotum. Elytra about $1.46 \times$ as long as broad, costal margins moderately diverging caudad, apical margins obliquely truncate with slight sublateral insinuation. Male genitalia (Figs. 3j-n, 7a-b): Pygofer broad and relatively short; dorsal margin of genital opening without median tooth. Right style shallowly curved, apical spine small. Left style as in $D$. sari. Sclerified middle process of vesica gracile, straight, narrowly blade-like, smooth; dentate membranous lobes as in Fig. 7a-b.

Female. Pale ochraceous. Dark pattern much less intense as seen in Fig. 6b. Middle of pronotum largely pale. Elytra with narrow longitudinal fuscous band, scutellar and commissural margins of clavus sometimes also dark. Dorsum of abdomen as in $\sigma^{7}$ or with larger pale areas. Antennae and legs as in $\sigma^{7}$. Body pyriform, 1.8-2.1 $\times$ as long as broad at broadest point of abdomen. Hair covering as in $0^{7}$. Head about $1.1 \times$ as broad as basal width of pronotum, in apical view $1.15 \times$ as 


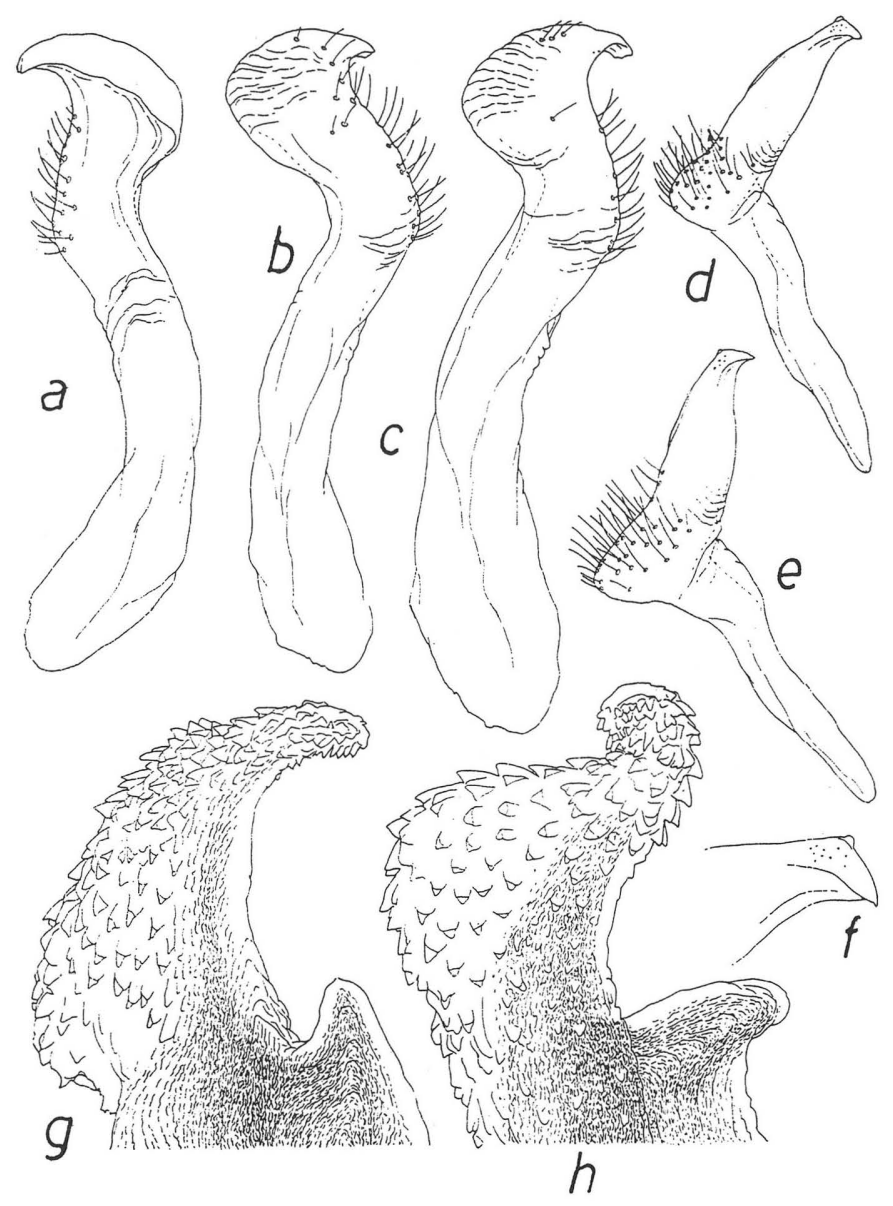

Fig. 5. Dimorphocoris servadeii Tamanini. a-c: right style; $d-$ e: left style; f: apex of hypophysis of left style; $g-h$ : structure of vesica. - After Tamanini 1982.

broad as high; ocular index 2.64-3.04. Proportions between antennal joints 35:75:58:31, 1st joint $0.83-0.95 \times$ as long as synthlipsis, 2 nd $1.78-$ $1.97 \times$ as long as synthlipsis, $1.03-1.19 \times$ as long as diatone, $1.23 \times$ as long as basal width of pronotum. Elytra about $1.26 \times$ as long as broad, costal margins curved, apical margins obliquely truncate. Abdomen 1.20-1.45 $\times$ as long as broad.

Biology: On grasses in undergrowth in olive gardens in Rhodes.

Distribution: Known from Libya, Crete, Rhodes, Naxos and Kos.

\section{Dimorphocoris eckerleini Wagner, 1965}

Figs. 6a, 7c-f

Type: Libya, Tripolitania, Jebel Nefoussa, Garian, ㅇ paratype, 29.IV.1965, Eckerlein, in Mus. Hamburg.

Material: Cyprus: Jermasoyia river, 1 ơ, 8.IV.1965, Mavromoustakis, in Mus. Hamburg. - Israel: Haifa, $10^{7}$, J. Sahlberg, in Mus. Helsinki. The specimen was recorded as D. punctiger in Reuter 1904:13-14, and later illustrated as D. lateralis in Lindberg 1956:61 (provided with label Pxt V. Nyström 56).

Diagnosis: Differing from $D$. lateralis in the punctate tibiae and structure of the male genitalia. 
Fig. 6. Dimorphocoris eckerleini Wagner. a: male from Haifa. $-D$. lateralis Reuter. b: female. $-D$. tristis (Fieber). c-d: male and female. - After Lindberg 1956.
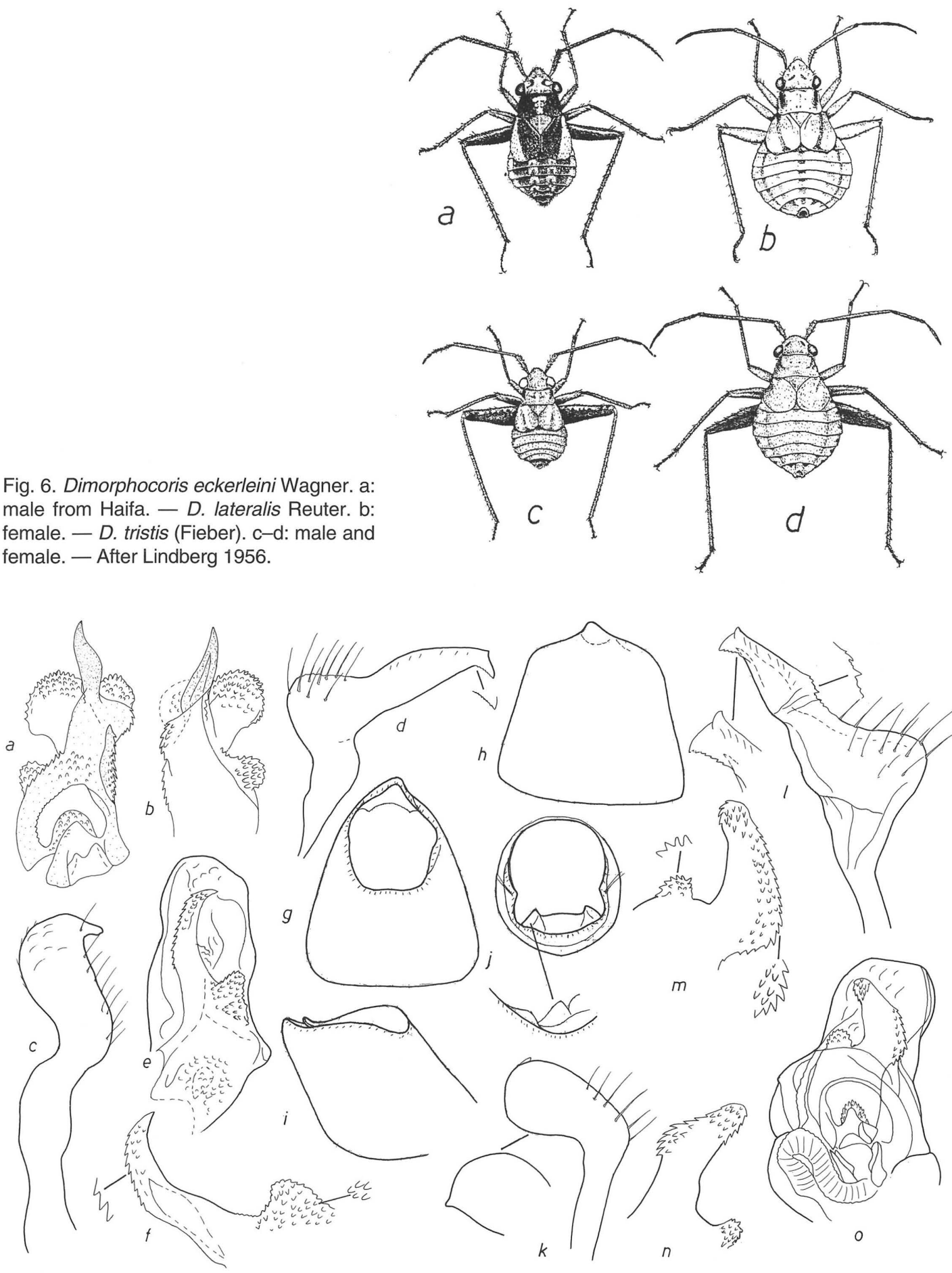

Fig. 7. Dimorphocoris lateralis Reuter. a-b: structure of vesica. $-D$. eckerleini Wagner (ex from Haifa). c: right style; d: left style; e-f: structure of vesica. - D. punctiger (Horváth). g-j: pygofer in dorsal, ventral, lateral and caudal view; k: right style; l: left style; $m-n$ : median process of vesica of two exx; o: vesica. 
Description: Length o' $3.0 \mathrm{~mm}$, o $3.0-3.5 \mathrm{~mm}$. Like $D$. lateralis, but tibiae with small dark setigerous dots.

Male. Body as in D. lateralis, but eyes smaller, ocular index 2.40-2.90. Head in apical view $1.1 \times$ as broad as high. 1st antennal joint $1.0-1.06 \times$ as long as synthlipsis, 2 nd 2.28-2.43 $\times$ as long as synthlipsis, $1.33-1.35 \times$ as long as diatone, $1.52-1.60 \times$ as long as basal width of pronotum. Male genitalia (Fig. 7c-f): Pygofer as in D. lateralis. Right style more strongly curved, apical part longer, apical tooth prominent. Median sclerified process of vesica sharply clawlike, dentate.

Female. Head in apical view $1.05 \times$ as broad as high; ocular index 2.9. 1st antennal joint 0.83 $\times$ as long as synthlipsis, 2nd twice as long as synthlipsis, $1.18 \times$ as long as diatone, $1.24 \times$ as long as basal width of pronotum. Elytra $1.32 \times$ as long as broad. Abdomen $1.6 \times$ as long as broad.

Distribution: More southern than in $D$. lateralis, extending from Libya to Cyprus and Northern Israel.

\section{Dimorphocoris punctiger (Horvath, 1881)}

Fig. $7 \mathrm{~g}-\mathrm{O}$

Material: Syria: Homs, several exx, 8-14.V.1952, Seidenstücker, in Mus. Helsinki and coll. Linnavuori.

Diagnosis: Differing from $D$. lateralis in the punctate tibiae and structure of the male genitalia.

Description: Length ơ $2.75 \mathrm{~mm}$, @ $3.50-3.75$ $\mathrm{mm}$. Resembling $D$. lateralis, but dark pattern on upper surface of body less intense and fainter. Tibiae with small dark setigerous dots.

Male. Body $2.63-2.70 \times$ as long as broad at broadest point of abdomen. Head $1.2 \times$ as broad as basal width of pronotum, in apical view $1.2 \times$ as broad as high; ocular index 2.13-2.52. Proportions between antennal joints 41:93:68:25; 1 st joint 1.21-1.34 $\times$ as long as synthlipsis, 2 nd 2.74 $3.20 \times$ as long as synthlipsis, $1.52-1.65 \times$ as long as diatone, 1.86-2.04 $\times$ as long as pronotum. Elytra about $1.3 \times$ as long as broad. Male genitalia (Fig. 7g-o): Pygofer longer, more sharply triangular. Right style with strongly bent apical part. Left style: ventral surface of apex of hypophysis finely serrate, middle of dorsal surface of hypophysis also dentate. Median process of vesica short, digitate, dentate.

Female. Body $1.76-1.80 \times$ as long as broad at broadest point of abdomen. Head $1.1 \times$ as broad as basal width of pronotum, in apical view $1.15 \times$ as broad as high; ocular index 2.83-2.93. Proportions between antennal joints 33:68:57:27; 1st joint $0.76-0.80 \times$ as long as synthlipsis, 2nd $1.55-$ $1.66 \times$ as long as synthlipsis, $0.90-1.0 \times$ as long as diatone, $1.0-1.1 \times$ as long as pronotum. Elytra about $1.1 \times$ as long as broad.

Distribution: Only known from Syria.

\section{Dimorpocoris tristis (Fieber, 1861)}

Fig. 6c-d

A well-known, small pale species, length $\sigma^{7}$ 1.7-2.0 mm, o 2.7-3.0 mm. Description in Wagner 1973:91-92.

Biology: On blooming Anthemis in sandy coastal habitats (Seidenstïcker 1957:180).

Distribution: Holomediterranean. Recorded from Greece (Seidenstücker 1957:180).

\section{References}

Josifov, M. 1990: Über die Verbreitung mancher Heteropteren auf der Balkanhalbinsel III. - Acta Zool. Bulgarica 40:3-11.

Lindberg, H. 1956: Über einige Miriden in E. de Bergevins Sammlung. - Notulae Entomol. 36:53-64.

Reuter, O. M. 1904: Capsidae novae mediterraneae. Öfvers. Finska Vetensk. Soc. Förhandl. 47(4):1-26.

Seidenstücker, G. 1957: Heteropteren aus Anatolien I. Rev. Fac. Sci. Univ. d'Istanbul 22:179-189.

Tamanini, L. 1982: Dimorphocoris servadeii n. sp., degli Apennini (Heteroptera Miridae). - Mem. Soc. Entomol. Ital. Genova 60: 335-341.

Wagner, E. 1965: Über die Gattung Dimorphocoris Reuter, 1891 (Hemiptera, Heteroptera, Miridae). — Reichenbachia 5:135-156.

- 1973: Die Miridae Hahn, 1831, des Mittelmeerraumes und der Makaronesischen Inseln (Hemiptera, Heteroptera). - Entomol. Abhandl. Staatl. Mus. Tierkunde Dresden, Suppl. 39(2). 421 pp.

Received 30.XI.1991 